\title{
Correction to: Temporal transcriptional patterns of cyanophage genes suggest synchronized infection of cyanobacteria in the oceans
}

Yue Chen ${ }^{1}$ and Qinglu Zeng ${ }^{1,2,3,4^{*}}$

\section{Correction to: Microbiome 8, 68 (2020) https://doi.org/10.1186/s40168-020-00842-9}

The below statement in the Background of the original article [1] was incorrect. Individual viral genes with diel transcriptional rhythms were in fact listed in the supplementary dataset S05 (Sheet 2) of Aylward et al. 2017 [2]. This statement therefore needs to be corrected as outlined below. This correction does not affect the results and conclusions.

The original text:

"However, it was not shown in this study whether individual viral genes in a scaffold show diurnal transcriptional rhythms, as the combined transcripts mapped to all the genes in a scaffold were used for diel periodicity analyses ([1] reference [2] in this correction)."

Corrected text:

Several viral genes in the scaffolds also showed diurnal transcriptional rhythms [2], but it remains to be determined whether the peak expression times of early, middle, and late cyanophage genes are different.

\section{Author details}

'Department of Ocean Science, The Hong Kong University of Science and Technology, Clear Water Bay, Hong Kong, China. 'Division of Life Science, The Hong Kong University of Science and Technology, Clear Water Bay,
Hong Kong, China. ${ }^{3}$ HKUST Shenzhen Research Institute, Shenzhen, China. ${ }^{4}$ Hong Kong Branch of Southern Marine Science and Engineering Guangdong Laboratory (Guangzhou), The Hong Kong University of Science and Technology, Clear Water Bay, Hong Kong, China.

Published online: 16 July 2020

\section{References}

1. Chen Y, Zeng Q. Temporal transcriptional patterns of cyanophage genes suggest synchronized infection of cyanobacteria in the oceans. Microbiome. 2020;8:68.

2. Aylward FO, Boeuf D, Mende DR, Wood-Charlson EM, Vislova A, Eppley JM, Romano AE, Delong EF. Diel cycling and long-term persistence of viruses in the ocean's euphotic zone. Proc Natl Acad Sci U S A. 2017;114:11446-51.

The original article can be found online at https://doi.org/10.1186/s40168020-00842-9.

*Correspondence: zeng@ust.hk

'Department of Ocean Science, The Hong Kong University of Science and Technology, Clear Water Bay, Hong Kong, China

${ }^{2}$ Division of Life Science, The Hong Kong University of Science and

Technology, Clear Water Bay, Hong Kong, China

Full list of author information is available at the end of the article

(c) The Author(s). 2020 Open Access This article is licensed under a Creative Commons Attribution 4.0 International License, which permits use, sharing, adaptation, distribution and reproduction in any medium or format, as long as you give appropriate credit to the original author(s) and the source, provide a link to the Creative Commons licence, and indicate if changes were made. The images or other third party material in this article are included in the article's Creative Commons licence, unless indicated otherwise in a credit line to the material. If material is not included in the article's Creative Commons licence and your intended use is not permitted by statutory regulation or exceeds the permitted use, you will need to obtain permission directly from the copyright holder. To view a copy of this licence, visit http://creativecommons.org/licenses/by/4.0/ The Creative Commons Public Domain Dedication waiver (http://creativecommons.org/publicdomain/zero/1.0/) applies to the data made available in this article, unless otherwise stated in a credit line to the data. 